\title{
Physico-chemical and sensory properties of pupuru and pupuru analogues from co-fermented cassava (Manihot esculenta Crantz) and
breadfruit (Artocarpus altilis) blends
}

O. F. Akinyele

e-mail: florenceakinyele@gmail.com

\author{
A. V. Ikujenlola ${ }^{1}$ \\ e-mail: avjenlola@gmail.com
}

\section{T. O. Omobuwajo \\ e-mail: tomobuwa@yahoo.com}

${ }^{1}$ Obafemi Awolowo University, Department of Food Science and Technology, Ile-Ife, Nigeria

Keywords and phrases: bulk density, co-fermented, hydrogen cyanide, proximate composition, sensory properties 
4.30-5.30, 0.18-0.31\%, and 0.56-1.68 mg/100 g respectively. The pupuru analogues had lower hydrogen cyanide content than pupuru. The pupuru analogues up to $50 \%$ breadfruit substitutions had acceptable sensory attributes, comparable to pupuru. The study concluded that pupuru analogues of acceptable quality can be produced from co-fermented cassava and breadfruit; this entails increasing the utilization of breadfruit.

\section{Introduction}

Breadfruit (Altocarpus altilis) is a crop native to Malaysia and countries of the South Pacific and Caribbean (Ajani et al., 2012). Other botanical names by which the plant is known include Artocarpus communis and Artocarpus incise. It is widely cultivated to an appreciable extent in the south-western states of Nigeria (Adejuyitan et al., 2018). The present level of breadfruit production in south-western Nigeria has been estimated at about 10 million tonnes of dry weight per year, with potential to exceed 100 million tonnes every year (NTBG, 2009; Ajani et al., 2016). This starchy fruit is sometimes round or oval in shape, with rough green skin, having pale yellow or white flesh. The fruit is high in carbohydrate, low in fat, protein, and is a good source of minerals (iron), vitamins, especially niacin, riboflavin, and pro-vitamin A (Ajatta et al., 2016). However, the traditional use of breadfruit is limited to boiled and pounded breadfruit among the "Ifes", but its use can be expanded by exploring other value-added products in this regard.

Fermentation is one method of processing cassava into another food form, which not only improves the flavour and taste of the product but extends its shelf life (Falade \& Akingbala, 2010). Acid production during cassava fermentation has been attributed to the activities of lactic acid bacteria on the carbohydrate content of cassava tuber (Oyewole \& Afolami, 2001). Fermentation enhances the reduction of the cyanide level and detoxification of the root (Kostinek et al., 2005). One of the notable products from fermented cassava is pupuru.

Pupuru, a fermented cassava product, is usually consumed by the people living in the riverine areas of the southern and middle belts of Nigeria, where it is also known as "Ikwurikwu" (Shittu et al., 2003; Daramola et al., 2010). Pupuru and other cassava products are widely accepted and consumed in Nigeria (Adejuyitan et al., 2018). It is moulded into the shape of a smoke ball, which is usually made into dough in boiling water before consumption with any desired soup (Ikujenlola \& Lawson, 2005). Breadfruit is nutritious, cheap, and available in high abundance during its season, while it also helps 
out the poor people in rural areas, providing them with an extra layer of food security (Omobuwajo, 2003). The expansion of breadfruit utilization has not been extended to the production of pupuru analogue. However, the putrid smell has limited its sensory acceptability, and there is also need for a further investigation into the physico-chemical properties of pupuru analogues to increase the utilization of breadfruit and make it a food of first choice, especially in several food deficit regions and countries. Hence, the objectives of this study were to produce pupuru analogue from co-fermented breadfruit and cassava blends and to evaluate the physico-chemical and sensory properties in a culturally familiar form, analogous to pupuru from cassava.

\section{Materials and methods}

Matured unripe breadfruits (Artocarpus altilis) and matured cassava root (Manihot esculenta) were purchased at Ilode and Tonkere markets in Osun State, Nigeria.

\section{Production of pupuru and pupuru analogue meals}

Cassava tuber and matured unripe breadfruits were washed and peeled. The cassava and breadfruit were mixed at different ratios of 100:0, 90:10, $80: 20,50: 50,20: 80,10: 90$, and 0:100 (wt/wt). It was sliced into easy-tomanage pieces using dicing machine. This is to ensure regular shape and size; this will guarantee the uniform fermentation of the diced pieces. The diced/sliced breadfruit and cassava roots were co-fermented (this is to allow for synergy in the fermentation process of the two biomaterials) in water (1:3 solid:water) inside a plastic container for $72 \mathrm{hrs}$ at ambient temperature (28$32^{\circ} \mathrm{C}$ ) to allow the inherent fermenting microorganisms to act on it and soften the pieces. The fermented mash was drained of excess water and the fibres were removed manually. Thereafter, the mash was packed inside bags and pressed using hydraulic press for 30 minutes to further reduce the water. The dewatered mash was moulded into balls of $5-10 \mathrm{~cm}$ in diameter. The moulded balls were smoked in the kiln dryer at $80^{\circ} \mathrm{C}$ for $6 \mathrm{hrs}$. In order to produce meal from the smoked balls, they were scraped of the dark outer portion of the balls, pulverized, sieved, and toasted $\left(>90^{\circ} \mathrm{C}\right)$ for $10 \mathrm{~min}$ in a traditional toaster. The toasted mass was cooled, re-milled, sieved (630 micron sieve), and packaged to obtain pupuru and pupuru analogue meals (Figure 1) (Ikujenlola \& Lawson, 2005). 
Fresh cassava roots

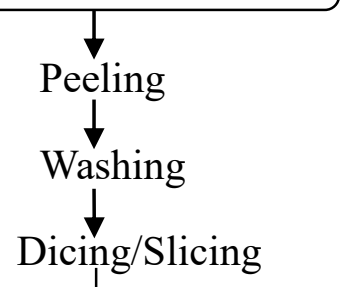

Matured unripe breadfruits

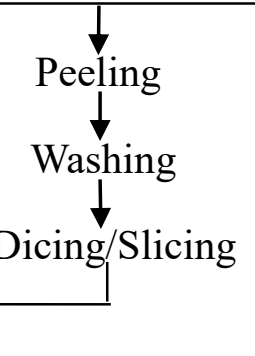

(72 hrs)

Soaking

$\downarrow$

Dewatering

Defibring

Pressing

(Removal of fibre)

Moulding

Smoking $\left(80^{\circ} \mathrm{C}, 6 \mathrm{hrs}\right)$

\section{Co-processed pupuru meal}

Source: Ikujenlola \& Lawson (2005)

Figure 1. Production of pupuru and pupuru analogue meals 


\section{Formulation of samples}

Table 1 shows the various pupuru and pupuru analogues produced from cassava and co-fermented cassava and breadfruit respectively.

\section{Chemical analysis}

The proximate compositions of the samples were determined using standard methods of AOAC (2010). The samples were analysed for moisture, ash, crude fibre, crude protein, crude fat, and carbohydrate. Calories was calculated using Atwater factors; the sum of $4 \times$ percentage of Protein, $4 \times$ percentage of carbohydrate, and $9 \times$ percentage of fat (Onoja et al., 2014).

Table 1. Formulation of pupuru and pupuru analogues from co-processed cassava and breadfruit

\begin{tabular}{ccc}
\hline Samples & Cassava & Breadfruit \\
\hline $100 \% \mathrm{PF}$ & 100 & - \\
$100 \% \mathrm{BP}$ & - & 100 \\
90:10 PF/BP & 90 & 10 \\
80:20 PF/BP & 80 & 20 \\
$50: 50 \mathrm{PF} / \mathrm{BP}$ & 50 & 50 \\
$20: 80 \mathrm{PF} / \mathrm{BP}$ & 20 & 80 \\
10:90 PF/BP & 10 & 90 \\
\hline
\end{tabular}

Source: Ikujenlola \& Lawson (2005)

Keys: 100\% PF - 100\% cassava; 100\% BP - 100\% breadfruits; 90:10 PF/BP - 90\% cassava co-processed with $10 \%$ breadfruits; 80:20 PF/BP - 80\% cassava co-processed with 20\% breadfruits; 50:50 PF/BP - 50\% cassava co-processed with 50\% breadfruits; 20:80 PF /BP - 20\% cassava co-processed with $80 \%$ breadfruits; 10:90 PF/BP $-10 \%$ cassava co-processed with $90 \%$ breadfruits

\section{Physico-chemical properties}

Bulk density

The bulk density was determined by the method of Okezie \& Bello (1988). A $10 \mathrm{ml}$ graduated cylinder, previously tared, was gently filled with the sample. The bottom of the cylinder was gently tapped on a laboratory bench several times until there was no further diminution of the sample level after filling to the $10 \mathrm{ml}$ mark. Bulk density was calculated as weight of sample per unit volume of sample $(\mathrm{g} / \mathrm{ml})$. 
The $\mathrm{pH}$ was measured by making a $10 \% \mathrm{w} / \mathrm{v}$ suspension of the sample in distilled water. The suspension was mixed thoroughly in a Sorex blender and the $\mathrm{pH}$ was measured with a Hanna checker pH meter (Model HI1270).

\section{Total titratable acidity}

The total titratable acidity of the sample was determined using the method described by AOAC (2010). Five grams of the sample was weighed in a clean beaker and $50 \mathrm{ml}$ of distilled water was added and homogenized, from which $25 \mathrm{ml}$ of the solution was taken into another conical flask, and three drops of $2 \%$ phenolphthalein indicator was added. The mixture was titrated against $0.1 \mathrm{~N}$ sodium hydroxide $(\mathrm{NaOH})$ until a permanent pink-coloured end-product was obtained. Total titratable acidity was calculated as follows and expressed as percentage lactic acid.

$$
\% \text { lacid acid }(\mathrm{wt} / \mathrm{vol})=N \cdot V \cdot E q \cdot w t \cdot W \cdot 1000 \cdot 100,
$$

where: $N=$ normality of titrant, usually $\mathrm{NaOH}(\mathrm{mEq} / \mathrm{ml}) ; V=$ volume of titrant $(\mathrm{ml}) ; E q . w t=$ equivalent weight of predominant acid $(\mathrm{mg} / \mathrm{mEq}) ; W=$ mass of sample $(\mathrm{g}) ; 1000=$ factor relating $\mathrm{mg}$ to gram $(\mathrm{mg} / \mathrm{g})(1 / 1000)$.

\section{Hydrogen cyanide determination}

The cyanogenic potentials of pupuru meals were determined using the picrate paper kits method as described by Bradburg et al. (1999). One gram sample of pupuru meal was homogenized in a $250 \mathrm{ml}$ conical flask containing $25 \mathrm{ml}$ of water. A strip of spot paper soaked in an alkaline sodium picrate solution was fixed in the solution with the cork; the flask was kept for $18 \mathrm{hrs}$ at $27^{\circ} \mathrm{C}$ (room temperature), the strip was removed and later eluted in 60 $\mathrm{ml}$, and the absorbance was read at $540 \mathrm{~nm}$ using a spectrophotometer. The hydrogen cyanide content was extrapolated using a cyanide standard curve.

\section{Sensory evaluation}

A voluntary panel of 15 judges made up of both males and females were selected from Obafemi Awolowo University, Ile-Ife. The selection was based on the fact that they were familiar with pupuru. The samples were placed on white plates coded with alphabetic letters under normal lighting condition at 
room temperature. Panellists were instructed in assessment terminology and requested to evaluate the various pupuru and pupuru analogue samples for taste, colour, aroma, texture, mouldability, and overall acceptability using a 9-point Hedonic scale as follows: $1=$ dislike extremely, $2=$ dislike very much, $3=$ dislike moderately, $4=$ dislike slightly, $5=$ neither like nor dislike, $6=$ like slightly, $7=$ like moderately, $8=$ like very much, and $9=$ like extremely (Iwe, 2002).

\section{Statistical analysis}

The data obtained were expressed as mean \pm standard deviation of nine experiments and were subjected to statistical analysis using one-way analysis of variance to determine the significant differences between means with significance level taken at $\alpha=0.05$. Tukey's least significant difference test was used to compare the means. All statistical procedures were carried out using SPSS version 17.0 (SPSS, Chicago, IL, USA).

\section{Results and discussion}

\section{Physical appearance and proximate composition of pupuru and pupuru analogues}

The pupuru and pupuru analogue meals produced from cassava and breadfruit, respectively, are presented in Figure 2. It was observed that pupuru had a brighter white colour compared to pupuru analogues, which are creamy in colour. The higher the proportion of breadfruit is, the darker the colour. The locally produced pupuru and industrial pupuru were of brighter colour.

The results of the proximate compositions of pupuru and pupuru analogues from cassava and cassava co-processed with breadfruit, respectively, are presented in Table 2. The protein content of all the pupuru analogues ranged between 2.86 and $6.41 \%$. It was observed that the protein content of pupuru analogues from $100 \%$ breadfruit was $6.41 \%$, which was the highest of all the samples. The protein content of pupuru from $100 \%$ cassava was higher than $0.55 \%$ as reported by Ojo et al. (2017) for 100\% cassava starch obtained from cassava starch-mushroom flour blends. It was observed that the protein content increased with increase in the level of substitution of breadfruit. The protein obtained was comparable with the range of $1.52-7.22 \%$ reported by Alozie et al. (2017) for gari fortified with soybeans, melon seed, and moringa seed flours. However, it was higher than the range (1.70-3.75\%) reported by 
Adejuyitan et al. (2018) for pupuru from breadfruit and tigernut flour. There was no significant difference $(\mathrm{p}>0.05)$ in the protein content of $100 \% \mathrm{BP}$ and 10:90 PF/BP. Padmaja \& Jisha (2005) reported that the protein content of cassava-based composite flours increased with the incorporation of legume flours.

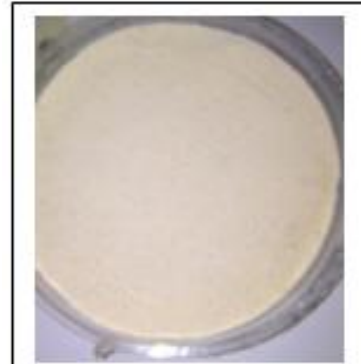

$100 \%$ PF

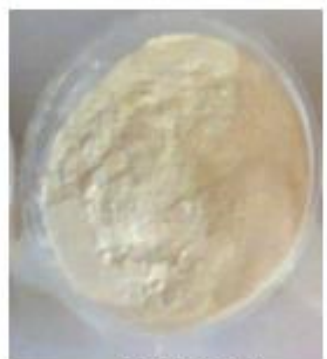

80:20 PF/BP

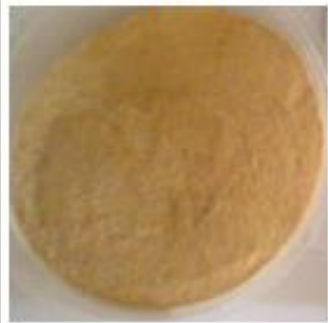

10:90 PF /BP

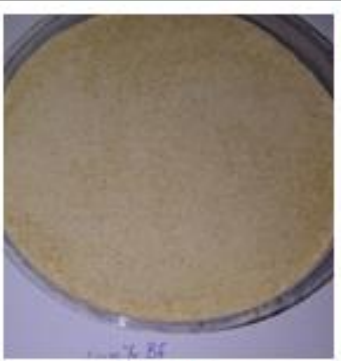

$100 \% \mathrm{BP}$

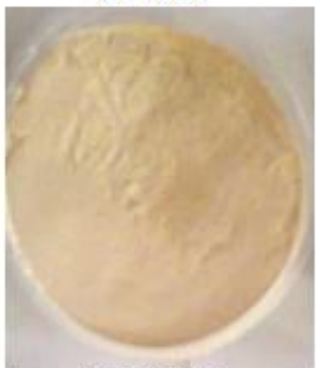

50:50 PF/BP

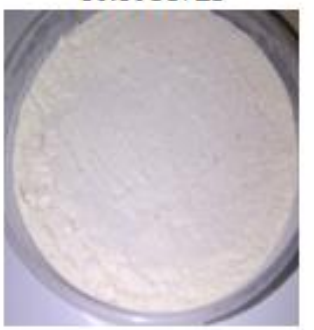

Locally made pupury (LMP)

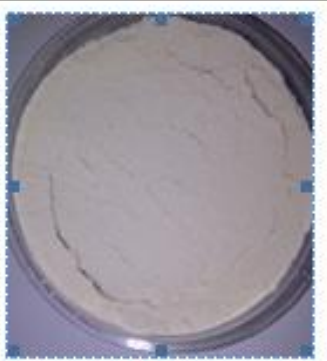

$90: 10 \mathrm{PF} / \mathrm{BP}$

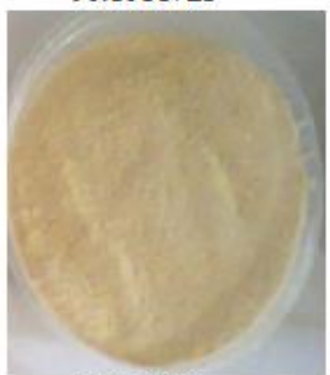

$8020 ; \mathrm{PF} / \mathrm{B}$

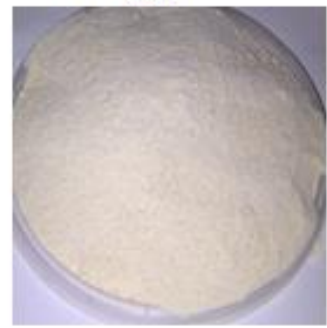

Industrial made pupuru (IMP)

Figure 2. Finished products of pupuru and pupuru analogue meals

Keys: $\mathbf{1 0 0 \%}$ PF - 100\% cassava; 100\% BP - 100\% breadfruits; 90:10 PF/BP - 90\% cassava co-processed with $10 \%$ breadfruits; 80:20 PF/BP - $80 \%$ cassava co-processed with 20\% breadfruits; 50:50 PF/BP - 50\% cassava co-processed with 50\% breadfruits; 20:80 PF / BP - 20\% cassava co-processed with $80 \%$ breadfruits; 10:90 PF/BP $-10 \%$ cassava co-processed with $90 \%$ breadfruits 

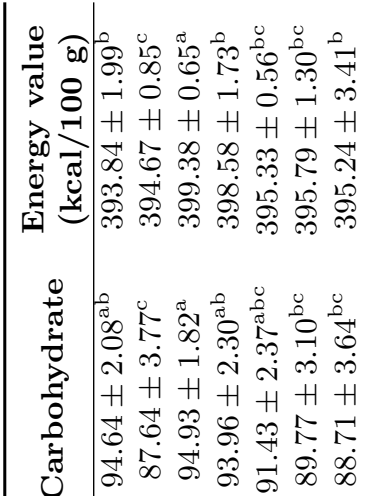

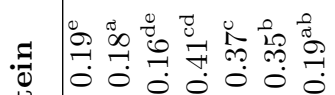

H H H H H H H

ค

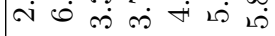

苞

$\begin{array}{ccccccc}0 & 0 & 0 & 0 & 0 & 0 & 0 \\ 0 & H & H & H & H & H & H\end{array}$

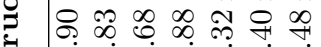

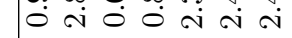

范

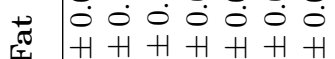

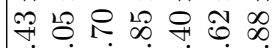

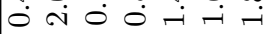

空

步 $\begin{array}{lllllll}0 & 0 & 0 & 0 & 0 & 0 & 0 \\ H & H & H & 0 & 0\end{array}$ 둥 ڤ.

-i $\dot{0} 0 \dot{0} 0 \dot{0}$

范

$\because 00000$

$\mathrm{H} H+\mathrm{H} H+\mathrm{H}$

ஓ

ㄷํำ ำ ำ

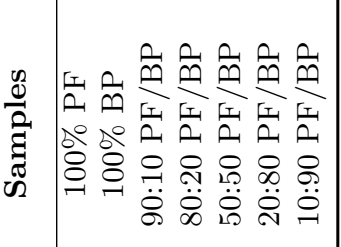

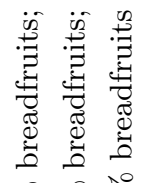

용 용

黄㕝黄

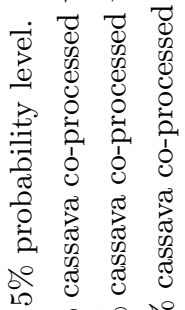

궁

离

곤 $\frac{x}{a}$ I

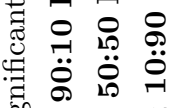

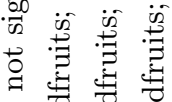

(艹)

ปี

.

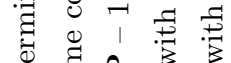

苍 㲾

ॠ

: $: 8$

की

¿

品

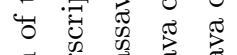

苛

ॠ

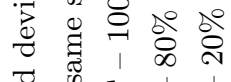

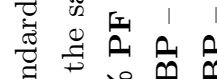

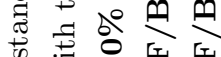

+ 药

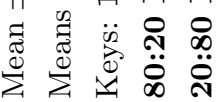


The ash content of the pupuru and pupuru analogues ranged between $0.36 \%$ and $1.17 \%$. The ash content of $100 \% \mathrm{PF}$ was the highest but was not significantly different $(\mathrm{p}<0.05)$ from that of $100 \% \mathrm{BP}$ and 10:90 PF/BP. The value obtained was lower than the range $(1.55-2.47 \%)$ recorded by Alozie et al. (2017) for gari fortified with soybean, melon seed, and moringa seed flours. The ash content of the pupuru analogue from $10 \%$ breadfruit $(0.36 \%)$ was comparable with $0.33 \%$ as reported by Monayajo \& Nupo (2011) for pupuru fortified with soy flour. However, ash values obtained in this study were lower than the maximum 3\% recommended by the Codex Alimentarius Commission (1995) for edible cassava flour.

The fat content of the pupuru and pupuru analogues ranged from 0.43 to $2.05 \%$. The pupuru analogue from $100 \%$ breadfruit had the highest fat content $(2.05 \%)$. $100 \% \mathrm{PF}$ had the lowest value $(0.43 \%)$. These values were higher than the range of $0.26-0.56 \%$ reported for cassava-African yam bean fufu blends by Nwokeke et al. (2013). It was observed that the fat content of pupuru analogue from $100 \%$ breadfruit was lower than $100 \%$ breadfruit pupuru analogue (3.25\%) as reported by Adejuyitan et al. (2018) but higher than the fat content of breadfruit flour (1.09\%) reported by Adepeju et al. (2011). The increase in the fat content of the products could be attributed to the increase in the substitution level of breadfruit.

Crude fibre contents increased with increase in the level of substitution of breadfruit. The value ranged between 0.68 and $2.83 \%$, with the highest in $100 \% \mathrm{BP}$ and the lowest value in 90:10 PF/BP. There was no significant difference $(\mathrm{p}>0.05)$ between the crude fibre of 100\% PF, 90:10 PF/BP and 80:20 PF/BP. However, they were significantly different $(\mathrm{p}<0.05)$ from those of 50:50 PF/BP and 20:80 PF/BP. The values were comparable to the crude fibre $1.34-2.01 \%$ from cassava-breadfruit fufu by Agbon et al. (2010) but lower than the values (1.38-5.11\%) reported by Adejuyitan et al. (2018) for pupuru flour from breadfruit and tigernut flour. The values in this study were higher than the $2 \%$ upper limit specified for edible cassava flour by the Codex Alimentarius Commission (1995). Crude fibre helps in maintaining the normal peristaltic movement of the intestinal tracts, thereby preventing colon diseases such as piles, cancer, or appendicitis (Famurewa \& Oluwalana, 2007).

The moisture content of the pupuru and pupuru analogues ranged between 11.47 and $12.98 \%$. The moisture content range in this study was lower than the range (12.10-14.00\%) reported for three traditional fermented cassava products by Shittu \& Adedokun (2010) but higher than the range (8.79-9.35\%) reported by Ojo et al. (2017) for cassava starch and mushroom blends. The moisture content of pupuru analogues from $50 \%$ and $80 \%$ breadfruit substi- 
tutions were significantly different $(\mathrm{p}<0.05)$ from $100 \% \mathrm{PF}$. The moisture content of flour products is a function of drying temperature, time, and loading depth (Ikujenlola \& Lawson, 2005). The higher the moisture content of food materials, the lower the shelf stability (Aluge et al., 2016). Generally, the moisture content of the products was within the acceptable levels (10-14\%) for flours (Butt et al., 2004).

The values of carbohydrate decreased from 94.93 to $87.64 \%$ with increase in the level of substitution of breadfruit. The value of the carbohydrate for 90:10 PF/BP was the highest as compared to other samples. There was no significant difference $(\mathrm{p}>0.05)$ between the values of the carbohydrate content for pupuru analogues substituted with $80 \%$ and $90 \%$ breadfruit. However, it was significantly different $(\mathrm{p}<0.05)$ from the values obtained for $100 \% \mathrm{PF}$ and 90:20 PF/BP. The decrease in the carbohydrate content of the analogues could be explained based on the lower level of carbohydrate present in breadfruit $(87.64 \%)$ compared to cassava $(94.93 \%)$. This observation agrees with the report of Agbon et al. (2010).

The energy value of pupuru and pupuru analogues ranged between 393.84 and $399.38 \mathrm{kcal} / 100 \mathrm{~g}$. It was observed that the energy value of pupuru analogue substituted with $10 \%$ breadfruit had the highest value of 399.38 $\mathrm{kcal} / 100 \mathrm{~g}$. There was no significant difference $(\mathrm{p}<0.05)$ between the energy value of pupuru analogues from $80 \%$ and $90 \%$ breadfruit substitution. The energy value of pupuru from 100\% cassava was higher than the value 363.73 $\mathrm{kcal} / 100 \mathrm{~g}$ (100\% cassava starch) for cassava starch-mushroom blends (Ojo et al., 2017). However, Alaba et al. (2013) reported reduced energy levels (358.03-359.32 kcal/100 g) for cassava flour.

\section{Physico-chemical properties}

The bulk density (Figure 3) ranged from 0.47 to $0.64 \mathrm{~g} / \mathrm{ml}$ with a significant difference $(\mathrm{p}<0.05)$. 100\% BP had the highest value $(0.64 \mathrm{~g} / \mathrm{ml})$ compared to other samples. There was no significant difference $(\mathrm{p}<0.05)$ between the bulk density of 50:50 PF/BP and 20:80 PF/BP. However, those of 10:90 PF/BP and 90:10 $\mathrm{PF} / \mathrm{BP}$ were the same. The range was comparable to the bulk density (0.40-0.62) reported by Alaba et al. (2013) for cassava flour ( $p$ upuru) but lower than $0.82-0.85 \mathrm{~g} / \mathrm{ml}$ for composite flours made from wheat, breadfruit, and cassava starch, as reported by Ajatta et al. (2016). Bulk density is a measure of heaviness of flour (Adejuyitan et al., 2009), and low bulk density is desired in flour blends as it contributes to lower dietary bulk, ease of packaging and transportation (Aluge et al., 2016). 


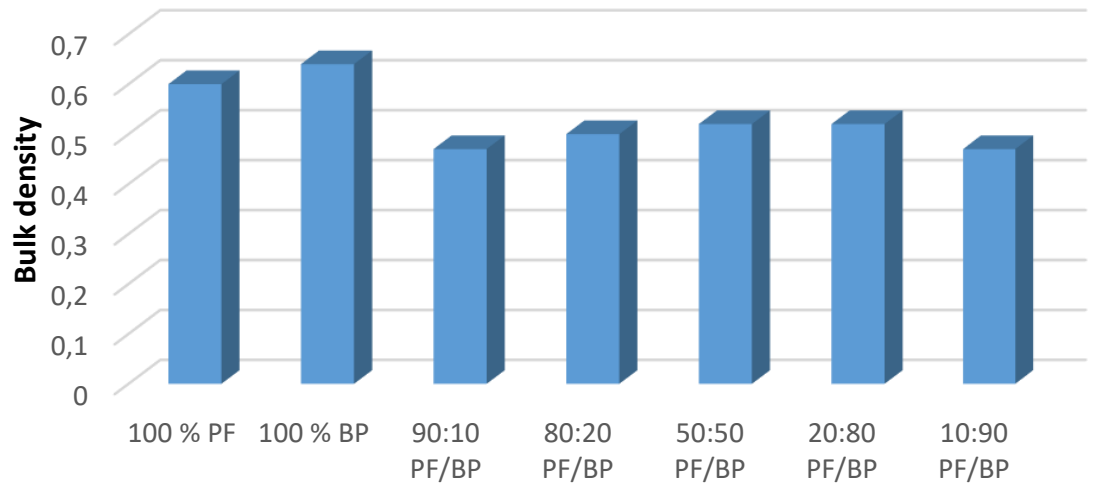

\section{Pupuru and pupuru analogue meals}

Figure 3. Bulk density $(\mathrm{g} / \mathrm{ml})$ of the pupuru and pupuru analogues

$\mathrm{pH}$ values (Figure 4) ranged between 4.37 and $5.30 . \mathrm{pH}$ value gives a measure of the acidity or alkalinity of the flour. The substitution of cassava in the pupuru analogues of breadfruit showed a gradual increase in the $\mathrm{pH}$ of the products. This was due to the $\mathrm{pH}$ of breadfruit, which was higher than that of cassava. There was no significant difference $(\mathrm{p}<0.05)$ between the $\mathrm{pH}$ of the pupuru $100 \% \mathrm{PF}$ and of pupuru analogues 20:80 PF/BP.

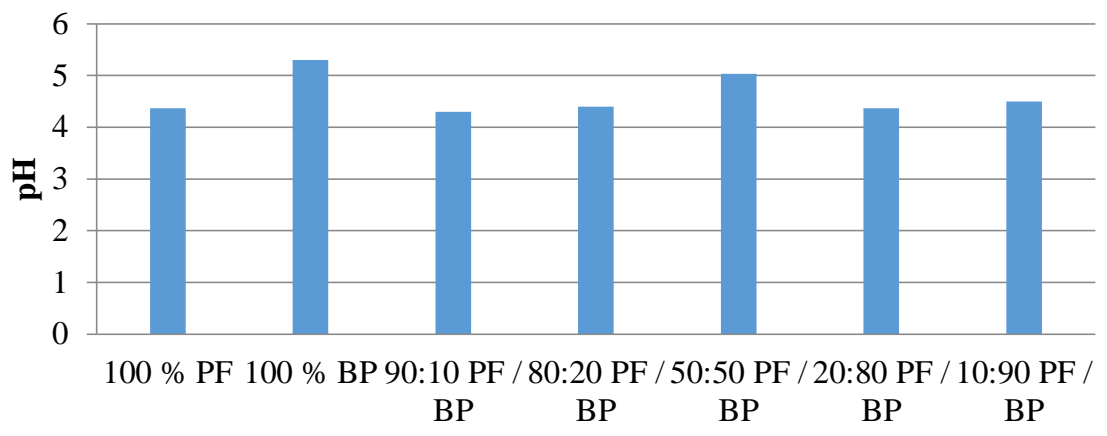

Pupuru and pupuru analogue meals

Figure 4. The $\mathrm{pH}$ of pupuru and pupuru analogue meals

The $\mathrm{pH}$ value of pupuru from $100 \%$ cassava (4.37) was lower than the value reported by Adejuyitan et al. (2018) for similar products. The $\mathrm{pH}$ decreased as a result of secretion of lactic acid, which implies that the more the cassava stays in the water during fermentation, the more there is reduction in the $\mathrm{pH}$ 
by the action of fermenting organisms. Acidic products are more shelf-stable than their non-acidic counterparts (Caballero et al., 2015).

The total titratable acidity (TTA) (Figure 5) expressed as percentage lactic acid of pupuru samples ranged between 0.18 and $0.31 \%$. There was no significant difference $(\mathrm{p}<0.05)$ in the total titratable acidity of all the samples. The value was higher than $0.13-0.16 \%$ for cassava flour (pupuru) as reported by Alaba et al. (2013). TTA values obtained for $100 \%$ BP are comparable to the value $(0.25 \%)$ for $100 \%$ breadfruit pupuru flour reported by Adejuyitan et al. (2018). Titratable acidity gives a measure of the amount of acid present in the food. The level of this index is used to estimate the quality of the flour. These values were in agreement with the Nigerian Industrial Standard recommendation of less than $10 \mathrm{~g} / 100 \mathrm{ml}$ total titratable acidity for gari samples. This shows that the period of fermentation of the various samples was adequate.

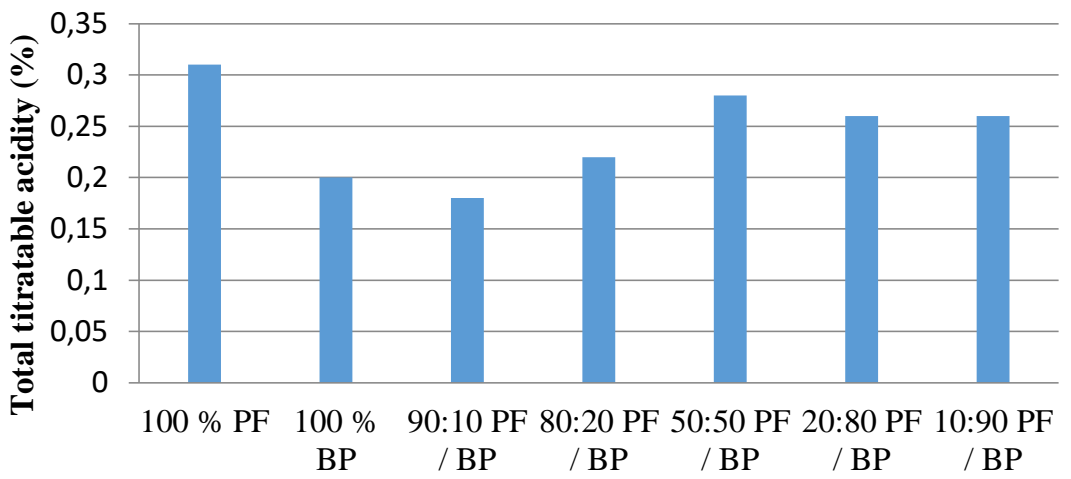

Pupuru and pupuru analogue meals

Figure 5. The total titratable acidity of pupuru and pupuru analogue meals

The cyanide concentration (Figure 6) of the pupuru samples ranged between 0.56 and $1.68 \mathrm{mg} / 100 \mathrm{~g}$. The pupuru analogues produced from $100 \%$ breadfruit had the least cyanide value $(0.56 \mathrm{mg} / 100 \mathrm{~g})$ while those from $100 \%$ cassava had the highest $(1.68 \mathrm{mg} / 100 \mathrm{~g})$. The cyanide content decreased as the level of substitution of breadfruit increased. Hydrogen cyanide (HCN) is the predominant antinutrient/toxic substance in cassava tubers and cassava products. The knowledge of cyanogenic glycoside content of food is vital because cyanide, being an effective cytochrome oxidase inhibitor, interferes with the aerobic respiratory system (Onwuka, 2005). The level of cyanide (0.42-0.47 $\mathrm{mg} / 100 \mathrm{~g}$ ) reported by Alaba et al. (2013) for cassava flour (pupuru) is lower than the values obtained. The reduction in cyanide could be attributed to the 
synergistic effect of loss by hydrolysis into the steep water during fermentation and toasting (Irtwange \& Achimba, 2009).

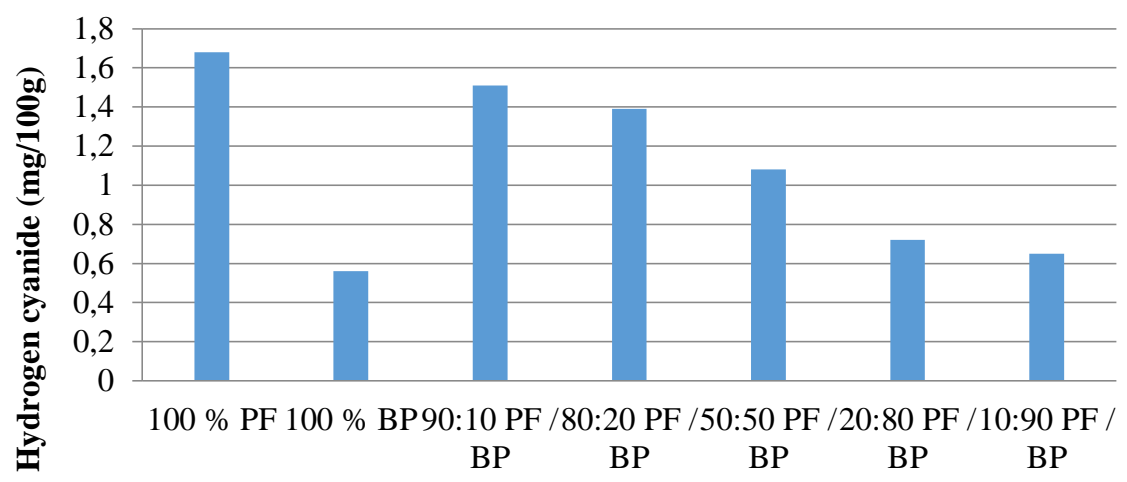

Pupuru and pupuru analogue meals

Figure 6. The hydrogen cyanide of pupuru and pupuru analogue meals

\section{Sensory evaluation}

Table 3 shows the results of the sensory evaluation of pupuru and pupuru analogues. The scores obtained for the colour of pupuru and pupuru analogues were significantly different $(\mathrm{p}<0.05)$ from each other, with 90:10 PF/BP having the most preferred colour (8.6). The scores for colour of locally (LMP) and industrially made pupuru (IMP) (7.47 and 7.07 respectively) were significantly different $(\mathrm{p}<0.05)$ from the colour of $100 \% \mathrm{PF}(5.40)$. There was the least preference for 10:90 PF/BP in terms of colour, texture, mouldability, and taste. Pupuru and pupuru analogues from 100\% PF, 50:50 PF/BF, locally-made pupuru (LMP), and 20:80 PF/BP did not differ significantly $(p<0.05)$ in terms of aroma and texture. However, the other samples were significantly different $(\mathrm{p}<0.05)$ from industrially-made pupuru (IMP). Usually, during smoking, there is a deposition of organic components, such as phenols, alcohols, aldehyde, or ketones, which influences flavour and the antimicrobial effects on the products (Tewe, 2004). In the case of mouldability, there was no significant difference ( $\mathrm{p}>0.05$ ) between $100 \% \mathrm{PF}, 100 \% \mathrm{BP}, 50: 50 \mathrm{PF} / \mathrm{BP}$, 20:80 PF/BP, and LMP respectively. Of all the samples, the $10 \%$ breadfruit substitution was the most acceptable meal. Meanwhile, pupuru analogues up to $50 \%$ breadfruit substitution had sensory attributes comparable to those of pupuru produced locally and industrially. 


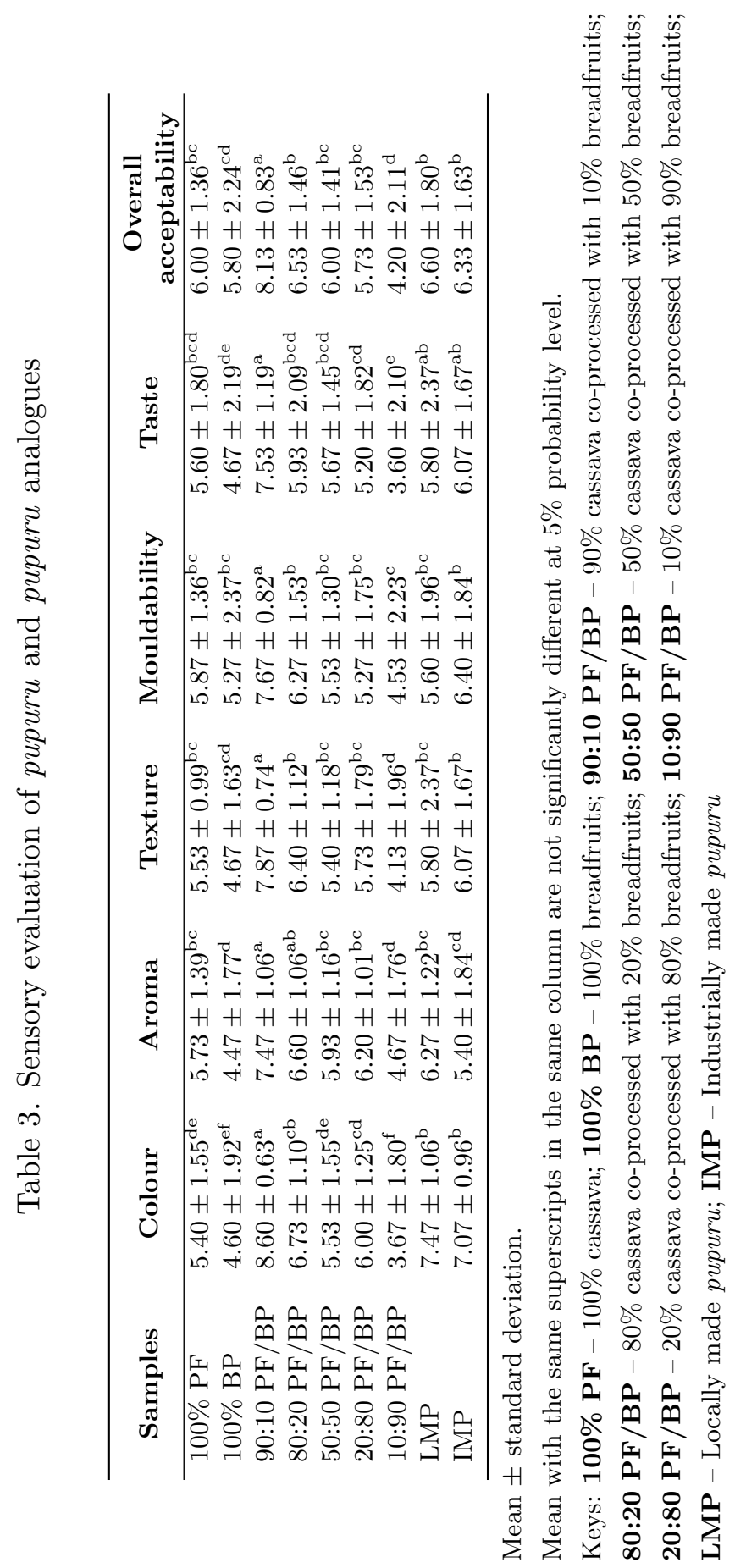


Results from this study suggest that the co-processing of cassava with breadfruit up to $50 \%$ breadfruit substitution will produce a meal that is acceptable, having a functional quality index. The abundance experienced during the breadfruit season in the south-western part of Nigeria can be exploited by utilizing breadfruit in the production of pupuru analogues. The value-added product can also boost the foreign earning of the country if the exportable product is exported to neighbouring countries. The local production of pupuru analogues is expected to be cheaper than the price per unit of pupuru made from cassava because breadfruit is abundant and cheaper.

\section{Conclusions}

The study concluded that pupuru analogues of acceptable sensory and physicochemical properties could be produced from cassava co-processed with breadfruit. The study provides valuable information regarding the utilization of breadfruit in food material, thereby preventing wastage of the crop during its season as well as expanding the use of breadfruit in food deficit regions.

\section{References}

[1] Adepeju, A. B., Gbadamosi, S. O., Adeniran, A. H., Omobuwajo, T. O., Functional and pasting characteristics of breadfruit (Artocarpus altilis) flours. African Journal of Food Science, 5. 9. (2011) 529-535.

[2] Adejuyitan, J. A., Otunola, E. T., Akande, E. A., Bolarinwa, I. F., Oladokun, F. M., Some physicochemical properties of flour obtained from fermentation of tigernut (Cyperus esculentus) sourced from a market in Ogbomoso Nigeria. African Journal of Food Science, 3. 2. (2009) $51-55$.

[3] Adejuyitan, J. A., Sulaiman, A. O., Kikelomo, O. I., Elizabeth, A. O., Characterisation of composition and sensory qualities of pupuru produced from breadfruit (Altocarpus altilis) and tigernuts flour. Asian Food Science Journal, 5. 3. (2018) 1-8. Article no AFSJ.42256.

[4] Agbon, C. A., Akinyemi, C. O., Adeleke, A., Okeke, E. C., Chemical and sensory characteristics of fufu made from mixtures of cassava and African breadfruit flours. Journal of Natural Sciences, Engineering and Technology, 9. 1. (2010) 84-89. 
[5] Ajani, A. O., Fasoyiro, S. B., Arowora, K. A., Ajani, O. O., Popoola, C. A., Zaka, K. O., Functional properties of composite flour made from wheat and breadfruit. Applied Tropical Agriculture, 21. (2016) 89-93.

[6] Ajani, A. O., Osundahunsi, O. F., Akinoso, R., Arowora, K. A., Aiodun, A. A., Pessu, P. O., Proximate composition and sensory quality of snacks produced from breadfruit flours. Global Journal of Science Frontier Research, 12. 7. (2012) 1-9.

[7] Ajatta, M. A., Akinola, S. A., Osundahunsi, O. F., Proximate, functional and pasting properties of composite flours made from wheat, breadfruit and cassava starch. Applied Tropical Agriculture, 21. 3. (2016) 158-165.

[8] Alaba, J. O., Famurewa, J. A. V., Oluwamukomi, M. O., Effect of different drying methods on the physicochemical characteristics of cassava flour ("pupuru"). International Journal of Biological and Chemical Sciences 7. 2. (2013) 832-839.

[9] Alozie, Y. E., Ekerette, N. N., Proximate compositions, physicochemical and sensory properties of gari fortified with soybean, melon seed and moringa seed flours. International Journal of Nutrition and Food Sciences, 6. 2. (2017) 105-110.

[10] Aluge, O. O., Akinola, S. A., Osundahunsi, O. F., Effect of malted sorghum on quality characteristics of wheat-sorghum-soybean flour for potential use in confectionaries. Food and Nutrition Sciences, 7. (2016) $1241-1252$.

[11] Association of Official Analytical Chemists (AOAC). Official Methods of Analysis. $19^{\text {th }}$ ed. Washington, D. C. (2010).

[12] Bradburg, G. M., Egan, S. V., Bradburg, J. H., Determination of all forms of cyanogens in cassava roots and cassava products using picrate paper kits. Journal of the Science of Food and Agriculture, 79. (1999) 593-601.

[13] Butt, M. S., Nasir, M., Akhtar, S., Sharif, M. K, Effect of moisture and packaging on the shelf life of wheat flour. International Journal of Food Safety, 4. (2004) 1-4.

[14] Caballero, B., Finglas, P., Toldrá, F., Encyclopedia of food and health. Academic Press. (2015). 
[15] Codex of Alimentarius Commission. Codex standard for edible cassava flour. Codex Standard 176-1989. (1995).

[16] Daramola, O. A., Idowu, M. A., Atanda, O. O., Oguntona, C. R. B., Effects of packaging material on the quality of "pupuru" flour during storage. African Journal of Food Science, 4. 5. (2010) 258-263.

[17] Falade, K. O., Akingbala, J. O., Utilisation of cassava for food. Food Reviews International, 27. (2010) 51-83.

[18] Famurewa, J. A. V., Oluwalana, I. B., Interactive effect of processing and varietal differences on the proximate composition of soyflour. Applied Tropical Agriculture, 12. 1. (2007) 38-42.

[19] Ikujenlola, A. V., Lawson, S. O., Improving the traditional processing technique of pupuru (a fermented cassava product). The Nigeria Journal of Research and Production, 6. 3. (2005) 103-108.

[20] Irtwange, S. V., Achimba, O., Effect of the duration of fermentation on the quality of gari. Current Research Journal of Biological Sciences Maxwell Scientific Organization, 1. 3. (2009) 150-154.

[21] Iwe, M. O., Sensory method and analysis. Published by Rejoint Communication Services, Enugu (2002) 49-72.

[22] Kostinek, M., Specht, I., Edward, V. A., Schillinger, U., Hertel, C., Holzapfel, W. H., Franz, C., Diversity and technological properties of predominant lactic acid bacteria from fermented cassava used for the preparation of gari a traditional African food. Systematic and Applied Microbiology, 28. (2005) 527-540.

[23] Monayajo, S. A., Nupo, S. S., Nutrient composition and acceptability of "pupuru" fortified with soy flour. Journal of Agriculture and Veterinary Sciences, 3. (2011) 28-31.

[24] NTBG. Hunger initiative. Breadfruit Institute. National Tropical Botanical Garden [http://www.ntbg.org/breadfruit/hunger.php] (2009) (last accessed: June 2016).

[25] Nwokeke, B., Adedokun, I., Osuji, C., Effect of blending on the proximate, pasting and sensory attributes of cassava-African yam bean fufu flour. International Journal of Scientific and Research Publications, 3. 8. (2013) $1-7$. 
[26] Ojo, M. O., Ariahu, C. C., Chinma, E. C., Proximate, functional and pasting properties of cassava starch and mushroom (pleurotus pulmonarius) flour blends. American Journal of Food Science and Technology, 5. 1. (2017) 11-18.

[27] Okezie, B. O., Bello, A. B., Physicochemical and functional properties of winged bean flour and isolate compared with soy isolate. Journal of Food Science, 53. (1988) 450-454.

[28] Omobuwajo, T. O., Compositional characteristics and sensory quality of biscuit, prawn-crackers and fried chips produced from breadfruit. Journal of Innovative Food Science and Emerging Technologies, 4. 2. (2003) 219-225.

[29] Onoja, U. S., Akubor, P. I., Gernar, D. I., Chinmma, C. E., Evaluation of complementary food formulated from local staples and fortified with calcium, iron and zinc. Journal of Nutrition and Food Science, 4. (2014) 326.

[30] Onwuka, G. I., Food Analysis and Instrumentation. Naphtali Publishers, Lagos Nigeria (2005).

[31] Oyewole, O. B., Afolami, O. A., Quality and preference of different cassava varieties for lafun production. African Journal of Food Technology, 6. (2001) 27-29.

[32] Padmaja, G., Jisha, S., Nutritional improved bean (Phaseolus vulgaris L.). Varieties characteristics of cassava based composite flours grown in East Africa. CIGRE Journal, 8. (2005) 1-18.

[33] Shittu, T. A., Adedokun, I. I., Comparative evaluation of the Functional and sensory characteristics of three traditional fermented cassava products. Journal of Natural Sciences, Engineering and Technology, 9. (2010) 109-110.

[34] Shittu, T. A., Oyewole, O. B., Olawuyi, O., Daramola, O., Processing technology of pupuru: A survey of practices and product quality in the South West of Nigeria. ASSET Series B, 2. 2. (2003) 17-27. 